ANATOLIAN STUDIES

\title{
PROFESSOR U. BAHADIR ALKIM
}

We deeply regret to learn of the death on 6 May 1981 of Professor U. Bahadir Alkım, an archaeologist well known to many members of the Institute and a regular contributor to our journal - his latest report is printed in the present volume. Dr R. D. Barnett writes as follows:

The death of Bahadir Alkım has removed a much-loved and distinguished figure from the scene of Anatolian archaeology. I first met Bahadir in August 1945. I was a Flight Lieutenant serving in the R.A.F. in Allied and Foreign Liaison and had to go to Aleppo to meet a party of Turkish army personnel who were on their way to Middle East Headquarters, Cairo, to learn radar engineering. Their Turkish escorting officer, likewise appointed for liaison, was a certain Lt. B. Alk1m, and we soon discovered that we had an absorbing interest in common the archaeology of Anatolia. To it Bahadir, ably supported by his wife and fellow-scholar, Handan Hanım, devoted his life. His modesty concealed the extent of his achievements. As the pupil, Dozent and Assistant of Professor H. T. Bossert he took a very prominent part in the epoch-making discoveries at Karatepe in 1947, which led to the decipherment of the Hittite hieroglyphs by providing the long-awaited bilingual inscription. He also conducted the excavations of Domuztepe, opposite Karatepe, and made a valuable exploration of the ancient road system of the south-western Anti-Taurus. In 1958 he moved southeast to the region of Islahiye, where for some twelve years he proceeded to direct excavations at Tilmen Hüyük, Gedikli and Kırışkal and made soundings at the neighbouring quarry site of Yesemek, where a sculptor's workshop and many remarkable neo-Hittite sculptures, some unfinished, came to light. During this period he took the opportunity to extend his investigations of the ancient road systems to the Amanus area. He soon succeeded Bossert in the Chair of Archaeology at Istanbul. Then from 1971 he turned his attention to the neglected North and began an exploration of the Black Sea coast near Samsun. Here he conducted a series of seasonal excavations at İkiztepe with striking success.

In latter years he suffered from chronic ill-health, but bore it bravely. He was an excellent linguist, always a popular figure at international gatherings, and a warm-hearted and loyal friend to all. We offer to his widow, family and colleagues our deeply-felt sympathies.

R. D. BARNETT 